\title{
PENGARUH SERTIFIKASI DAN MOTIVASI KERJA TERHADAP MINAT GURU BIMBINGAN KONSELING UNTUK MENGIKUTI PENDIDIKAN LANJUT
}

\author{
Sardjono Gatut Prijono*
}

\begin{abstract}
Abstrak
Penelitian ini bertujuan untuk menganalisis pengaruh dimensi program sertifikasi dan motivasi kerja terhadap minat guru Bimbingan Konseling untuk mengikuti Pendidikan Lanjut setelah menempuh jenjang S1. Populasi penelitian adalah guru Bimbingan Konseling yang berada di Kabupaten Madiun. Sampel penelitian berjumlah 28 dari 9 sekaloh yang terdiri SMA/SMK/MA Negeri-Swasta. Variabel independen dalam penelitian ini yaitu program sertifikasi dan motivasi kerja, sedangkan variabel dependennya adalah minat mengikuti pendidikan lanjut. Pengumpulan data dilakukan dengan kuesioner, dan data dianalisis dengan menggunakan metode analisis korelasi dan regresi berganda. Hasil penelitian menunjukkan bahwa program sertifikasi guru dan motivasi kerja secara bersama-sama berpengaruh terhadap minat untuk mengikuti pendidikan lanjut, hal tersebut ditunjukkan oleh koefisien korelasi $(r)=0,6209$,dan koefisien determinan $\left(r^{2}\right)=0,3855$ dengan demikian menunjukkan bahwa sumbangan sertifikasi dan motivasi kerja terhadap minat guru bk mengikuti pendidikan lanjut sebesar 38,55\% .
\end{abstract}

Kata kunci: Sertifikasi, Motivasi Kerja, Minat Pendidikan Lanjut.

* Sardjono Gatut Prijono adalah Dosen Bimbingan dan Konseling IKIP PGRI Madiun 


\section{Pendahuluan}

Pemberlakuan peraturan perundang-undangan yang berkaitan dengan pelaksanaan otonomi pendidikan menuntut adanya upaya pembagian kewenangan dalam berbagai bidang, hal tersebut membawa implikasi terhadap sistem dan penyelenggaraan pendidikan Pembangunan di bidang pendidikan sampai saat ini masih menjadi prioritas utama dalam upaya peningkatan kualitas sumber daya manusia. Pendidikan menjadi barometer kemajuan suatu bangsa, oleh karenanya kebijakan pemerintah dalam pendidikan mengacu kepada suatu upaya strategi pencapaian tujuan pendidikan nasional. Kebijakan pemerintah dalam bidang pendidikan memberikan arah kepada lembaga-lembaga di lingkungan Kementrian Pendidikan Nasional untuk melaksanakan program-program operasional di tingkat implementasi.

Penyelenggaraan pendidikan menuntun kepada suatu sistem kerja yang tidak parsial, karena penyelenggaraan pendidiakan terjadi karena adanya jaringan kerja sama dari berbagai komponen yang ada di dalam lembaga pendidikan (sekolah) ataupun lembaga lain. Salah satu komponen yang sangat menentukan berhasil atau tidaknya penyelenggaraan pendidikan adalah guru termasuk di dalamnya guru bimbingan konseling. Guru sebagai ujung tombak pendidikan yang langsung berada di garis depan berhadapan dengan siswa dituntut memiliki kompetensi yang memadai. Melalui guru penanaman nilainilai dan pembelajaran berbagai ilmu pengetahuan, pengalaman dan keterampilan yang relevan dengan masa kini dan masa depan dapat berlangsung. Guru dapat menjadi model untuk suatu keahlian, strategi pemecahan masalah, kode moral, standar performa, aturan dan prinsip umum serta kreativitas. (Hergenhahn, 2008 :385).

Pada hakekatnya guru bimbingan konseling adalah juga pendidik profesional dengan tugas utama mendidik, membimbing, mengarahkan, melatih, menilai, dan mengevaluasi peserta didik, dan kontek tugasnya sebagai konselor adalah kondisi pribadi klien yang menyangkut penyesuaian diri, sikap dan kebiasaan belajar, informasi, pilihan karer dan sebagainya (Prayitno, 2008). Pengakuan kedudukan guru sebagai tenaga profesional dibuktikan dengan sertifikat pendidik yang diperoleh melalui sertifikasi, dengan dasar utama pelaksanaan sertifikasi tersebut diantaranya adalah Undang-Undang Nomor 14 Tahun 2005 tentang Guru dan Dosen. Selanjutnya pasal yang menyatakan diantaranya adalah pasal 8 yaitu guru wajib memiliki kualifikasi akademik, kompetensi, sertifikat pendidik, sehat jasmani dan rohani, serta memiliki kemampuan untuk mewujudkan tujuan pendidikan nasional. Pasal lainnya adalah pasal 11, ayat (1) menyebutkan bahwa sertifikat pendidik sebagaimana dalam pasal 8 diberikan kepada guru 
yang telah memenuhi persyaratan, disamping itu tentunya juga memiliki motivasi kerja yang cukup tinggi. Guru adalah suatu profesi, merupakan jabatan atau pekerjaan yang memiliki fungsi dan kebermaknaan sosial yang sangat menentukan, mampu menampilkan pelayanan yang didasarkan atas teknik-teknik intelektual dan ketrampilan. Pelayanan tersebut bukan hanya dilakukan secara rutin saja melainkan bersifat pemecahan masalah atau penanganan situasi kritis yang menuntut pemecahan dengan menggunakan teori dan metode ilmuah, selanjutnya untuk dapat menguasi kerangka ilmu tersebut diperlukan pendidikan dalam jangka waktu yang cukup lama (Prayitno, 2008:339)

Pemerintah berharap semua guru termasuk guru bimbingan konseling menjadi guru yang profesional, yakni memiliki kemampuan dan kompetensi yang lebih baik dalam bidangnya untuk ditransfer kepada anak didiknya. Berbagai langkah perbaikanpun dilakukan Kemendiknas, misalnya yang mulanya peningkatan kompetensi dilakukan dengan sertifikasi melalui dokumentasi portofolio kini Kemendiknas merubahnya menjadi paletihan melalui PLPG, dan selain itu para guru yang telah bersertifikasi dievaluasi secara berkala. (Jawa Pos : 24/8/2011). Mengingat tugas guru begitu berat maka perlunya guru untuk selalu menumbuh kembangkan pengetahuan, wawasan, keterampilannya menuju kepada pengembangan profesi yang diharapkan, baik lewat kegiatan pelatihan maupun dengan melanjutkan pendidikan. Menurut peneliti dari hasil obseservasi dan wawancara terhadap responden dilapangan yang dilaksanakan bulan Agustus 2011 yang lalu mayoritas guru bimbingan konseling masih memerlukan berbagai pengetahuan dan informasi dalam menunjang tugasnya, tetapi kegiatan pelatihan dan sejenisnya bagi guru bimbingan konseling terbatas jikalau ada peserta yang dikirim dalam satu kabupaten/kota hanyalah beberapa orang peserta, hal ini masih kurang memadai. Menghadapi tuntutan pengembangan kompetensi profesi yang demikian salah satu alternatif yang bisa dilakuan adalah dengan belajar atau mengikuti pendidikan lanjut.

Belajar merupakan hal yang erat kaitannya dengan prinsip ekonomi, tegasnya makin cepat seseorang belajar dengan prestasi yang sama maka makin baiklah keadaan berikutnya (Bimo Walgito :2010), belajar merupakan proses terasosiasinya gagasangagasan baru dengan gagasan-gagasan lama yang sudah membentuk pikiran, dan dalam proses belajar tersebut faktor lingkungan juga turut memegang peran penting, pengertian lingkungan di sini termasuk tempat, alat untuk belajar, suasana, waktu dan pergaulan serta segi finansial. Guru bimbingan konseling dalam menjalankan aktivitas nantinya tidak akan lepas dari hal tersebut, sehingga minat belajar ke pendidikan lanjutpun patut untuk dikaji. 
Berdasarkan fenomena dan latar belakang masalah di atas, maka permasalahan yang akan diteliti adalah apakah program sertifikasi dan motivasi kerja berpengaruh terhadap minat guru bimbingan konseling mengikuti pendidikan lanjut .

Penelitian ini bertujuan untuk menganalis pengaruh program sertifikasi dan motivasi kerja terhadap minat guru bimbingan konseling mengikuti pendidikan lanjut, hasil penelitian ini diharapkan dapat bermanfaat bagi lembaga penyelenggara pendidikan dan organisasi profesi tentang informasi minat guru bimbingan konseling dalam mengikuti pendidikan lanjut sebagai bahan koordinasi dan pembinaan.

\section{Metode Penelitian}

Penelitian ini menggunakan pendekatan kuantitatif - non eksperimental menekankan fenomena keobyektifan menggunakan angka-angka dengan pengolahan statistik, dan subyek dalam penelitian ini adalah guru Bimbingan Konseling dari 9 (sembilan ) sekolah jenjang SMA, SMK dan MA Negeri - Swasta yang berada di Kabupaten Madiun.

Teknik pengumpulan data yang dilakukan dalam penelitian ini dengan cara memberi seperangkat pertanyaan atau pernyataan secara tertulis pada responden untuk dijawab, dan jawaban setiap item instrumen menggunakan acuan skala Likert mempunyai gradasi angka terendah hingga tertinggi (Sugiyono, 2010 : 134), dan untuk keperluan analisis kuantitaif maka jawaban tersebut diberi skor. Validitas instrumen dalam penelitian ini digunakan content validity, supaya penyusunan instrumen lebih sistematis mudah dikontrol dan dikoreksi maka dibuatlah kisi-kisinya, selanjutnya pengujian validitas dilakukan dengan mengkorelasikan skor item dengan skor total. Untuk mengukur variabel sertifikasi digunakan 16 item, untuk variabel motivasi kerja digunakan 20 item dan variabel minat diungkapkan dengan 20 item .

Metode analisis data yang digunakan adalah analisis korelasi dan regresi ganda, yaitu dengan mencari tiga rukun dasar untuk (Arikunto : 265) : (1) menyatakan hubungan variabel, (2) Standart error of estimate (SY, X1, X2), dan (3) koofisien (r) angka yang menyatakan eratnya hubungan antara ketiga variabel tersebut.dan pengujian signifaikansi dengan uji $\mathrm{F}$

Dari output data di atas dapat dibuat resume interpretasi korelasi yang menyatakan ada atau tidak korelasinya dengan ketentuan sebagai berikut :

1. Bila koefisien korelasi bertanda positif, menunjukkan arah korelasinya positif (searah), mengandung pengertian semakin tinggi sector variable pertama maka semakin tinggi 
pula sector variable kedua. Sebaliknya semakin rendah sector variable pertama maka sector variable kedua semakin rendah.

2. Bila koefisien korelatif bertanda negative. Menunjukkan arah korelasinya negative (berlawanan arah), mengandung pengertian semakin tinggi sector variable pertama maka semakin rendah pula sector variable kedua, sebaliknya semakin rendah variable pertama maka sector variable kedua semakin tinggi.

\section{Hasil Penelitian}

Hasil pengolahan dan pengujian data yang diperoleh menunjukkan bahwa :

1). Dari data perhitungan menyatakan adanya hubungan yang positif antara variabel sertifikasi dengan minat guru pada pendidikan lanjut sebesar 0,236 dan hubungan yang

positif antara motivasi kerja dengan minat guru pada pendidikan lanjut dengan besaran 0,095

2).Penghitungan Standard Error of Estimate - besaran Sy, $X 1, X 2$

Tabel Penghitungan Sy,X1,X2

\begin{tabular}{|c|c|c|c|c|c|c|c|c|c|}
\hline No & $\mathrm{Y}$ & $\mathrm{Yc}$ & $\mathrm{Y}-\mathrm{Yc}$ & $(\mathrm{Y}-\mathrm{Yc})^{2}$ & $\mathrm{No}$ & $\mathrm{Y}$ & $\mathrm{Yc}$ & $\mathrm{Y}-\mathrm{Yc}$ & $(\mathrm{Y}-\mathrm{Yc})^{2}$ \\
\hline 1 & 60 & 58,917 & 1,08 & 1,172889 & 15 & 53 & 56,636 & $-3,64$ & 13,220496 \\
\hline 2 & 52 & 52,04 & $-0,04$ & 0,0016 & 16 & 52 & 53,791 & $-1,79$ & 3,207681 \\
\hline 3 & 58 & 54,664 & 3,34 & 11,128896 & 17 & 67 & 61,28 & 5,72 & 32,7184 \\
\hline 4 & 52 & 53,284 & $-1,28$ & 1,648656 & 18 & 53 & 53,963 & $-0,96$ & 0,927369 \\
\hline 5 & 62 & 57,227 & 4,77 & 22,781529 & 19 & 51 & 51,973 & $-0,97$ & 0,946729 \\
\hline 6 & 55 & 54,415 & 0,59 & 0,342225 & 20 & 57 & 58,099 & $-0,10$ & 1,207801 \\
\hline 7 & 53 & 54,979 & $-1,98$ & 3,916441 & 21 & 51 & 53,816 & $-2,82$ & 7,929856 \\
\hline 8 & 55 & 55,104 & $-0,10$ & 0,010816 & 22 & 51 & 48,293 & 2,71 & 7,327849 \\
\hline 9 & 58 & 54,126 & 3,87 & 15,007876 & 23 & 55 & 55,985 & $-0,98$ & 0,970225 \\
\hline 10 & 55 & 54,633 & 0,37 & 0,134689 & 24 & 51 & 50,712 & 0,29 & 0,082944 \\
\hline 11 & 53 & 55,401 & $-2,40$ & 5,764801 & 25 & 52 & 49,672 & 2,33 & 5,419584 \\
\hline 12 & 52 & 53,929 & $-1,93$ & 3,721041 & 26 & 50 & 50,889 & $-0,89$ & 0,790321 \\
\hline 13 & 56 & 56,025 & $-0,02$ & 0,000625 & 27 & 52 & 51,519 & 0,48 & 0,231361 \\
\hline 14 & 53 & 51,056 & 1,94 & 3,779136 & 28 & 62 & 59,905 & 2,10 & 4,389025 \\
\hline
\end{tabular}

Dengan tabel angka tersebut maka diperoleh besaran (Sy, X1, X2) sebesar 2,347 dengan pembulatan 2,35 
3) Koofisien korelasi dari variance harga $Y$ diperoleh angka $r$ sebesar 0,6209, sedangkan $r$ tabel dengan $\mathrm{n}=28$ menunjuk angka 0,374 pada tk $5 \%$ dan angka 0,478 pada tk $1 \%$ Memperhatikan perhitungan tersebut bahwa koofisien sebesar 0,6209 berarti lebih besar dari $r$ tabel, dan, koefisien determinan $\left(\mathrm{r}^{2}\right)=0,3855$. Uji signifikan hubungan dengan menggunakan rumus uji $\mathrm{F}$ dengan taraf kesalahan 1\% - 5\% diperoleh besaran 7,837 > $5,57>3,38$

Artinya terdapat pengaruh antara seritifikasi dan motivasi kerja terhadap minat guru bimbingan konseling untuk mengikuti pendidikan lanjut. Keofisien determinasi sebesar 0,3855 memperlihatkan bahwa program sertifikasi dan motivasi kerja memberikan sumbangan sebesar $38,5 \%$, selanjutnya masih ada pengaruh $61,5 \%$ dari variabel lain terhadap minat guru bimbingan konseling mengikuti pendidikan lanjut.

\section{Pembahasan}

Berdasarkan hasil penelitian antara program sertifikasi dan motivasi kerja dengan minat guru bimbingan konseling terhadap pendidikan lanjut terdapat hubungan positif, hal ini menunjukkan bahwa apa yang menjadi ketentuan dari pemerintah yang tertuang dalam Undang-Undang Nomor 14 Tahun 2005 tentang Guru dan Dosen khususnya pasal 8 dan 11 berimplikasi di lapangan . Pelaksanaan program sertifikasi memiliki tujuan menentukan kelayakan guru dalam melaksanakan tugas sebagai agen pembelajaran untuk mewujudkan tujuan pendidikan nasional, meningkatkan proses dan mutu hasil pendidikan,meningkatkan martabat guru serta meningkatkan profesionalitas guru.(lsmmper.blogspot.com). Keefektifan pelaksanaan peran sebagai agen pembelajaran tergantung pada tingkat kompetensi guru bk yang bersangkutan, yang mencakup domain kompetensi pedagogik, kompetensi kepribadian, kompetensi sosial, dan kompetensi profesional, seperti disebutkan dalam Permendiknas Nomor 27 Tahun 2008 bahwa dari keempat domain tersebut memiliki 17 kompetensi inti.

Setiap guru profesional harus menguasai pengetahuan yang mendalam dalam spesialisasinya penguasaan pengetahuan ini merupakan syarat yang penting disamping ketrampilan-ketrampilan lainnya dan hal tersebut faktor pendukung dalam mendukung peranannya. Pandangan modern yang dikemukakan oleh Adam \& Dicky ( Hamalik 2004:123) bahwa peran guru sesungguhnya sangat luas meliputi :(1) guru sebagai pengajar, (2) guru sebagai pembimbing, (3) guru sebagai ilmuwan, (3) guru sebagai pribadi, dan dalam arti yang luas dimana sekolah berfungsi sebagai penghubung antara guru, ilmu dan teknologi dengan masyarakat. 
Lebih lanjut Mulyasa (2005:143) menjelaskan bahwa guru dalam aktivitas atau perannyanya tidak terlepas dari lembaga sekolah atau organisasi, keberhasilannya dipengaruhi oleh berbagai faktor, dan faktor motivasi merupakan suatu faktor dominan yang dapat menggerakkan faktor-faktor lain ke arah efektifitas kerja. Mengacu pada pendapat tersebut dapat dikemukakan bahwa motivasi merupakan suatu bagian yang sangat penting dalam suatu lembaga, guru akan bekerja dengan sungguh-sungguh apabila memiliki motivasi yang tinggi, ia akan memperlihatkan minat, mempunyai perhatian, dan ingin ikut serta dalam suatu tugas atau kegiatan.

Teori motivasi dengan model expectancy atau expectancy-velence model yang dikembangkan Edwards dan Atkinson (Djiwandono:342), menyebutkan bahwa motivasi manusia untuk mencapai sesuatu tergantung pada hasil perkiraan mereka akan adanya kesempatan untuk sukses dan nilai yang mereka tempatkan pada sukses, motivasi secara sederhana adalah hasil reinforcement dan konsep motivasi berkaitan erat dengan prinsipprinsip bahwa tingkah laku yang telah diperkuat pada waktu yang lalu barangkali diulang , begitu pula dalam motivasi kerja. Motivasi kerja sebenarnya menunjuk pada dorongan yang timbul dalam diri seseorang untuk meningkatkan kemampuan pribadinya dalam rangka mencapai kedudukan, jabatan/karir yang lebih baik dari sebelumnya, dan selanjutnya peningkatan kemampuan bisa diperolehnya dengan mengikuti berbagai kegiatan diantaranya dengan mengikuti pendidikan lanjut. Minat mengikuti pendidikan lanjut hakekatnya adalah guru akan melakukan belajar, dan inti perbuatan belajar adalah upaya untuk menguasai sesuatu yang baru dengan memanfaatkan apa yang sudah ada pada diri individu (Prayitno 2008:163)

Hasil penelitian sejalan dengan pendapat Mappiare,(1983:62) bahwa pola perubahan minat dapat terjadi penguatan minat-minat baru jika lingkungan memaksa, dan sifat-sifat minat baru itu tidak sekelompok dengan minat-minat yang telah dimantapkan sebelumnya, demikian pula dengan minat terhadap pendidikan atau sekolah yang tiba-tiba muncul dapat disebabkan oleh tuntutan lingkungan kerja. Lebih lanjut dikatan oleh Throndike bahwa perilaku belajar manusia ditentukan oleh stimulus yang ada di lingkungan sehingga menimbulkan respon secara refleks, jika sebuah tindakan diikuti oleh perubahan yang memuaskan dalam lingkungan maka kemungkinan tindakan itu akan diulang kembali semakin meningkat (Baharrudin:65), sehingga sertifikasi dan motivasi kerja bisa dikatakan sebagai suatu bentuk stimulus yang dapat mendorong minat guru.

Dalam konsep belajar humanisme dinyatakan bahwa proses belajar bukanlah sebagai sarana transformasi pengetahuan saja tetapi lebih dari itu, proses belajar 
merupakan bagian dari mengembangkan nilai-nilai kemanusiaan. Gagasan John P. Miler (Baharudin :143) dalam model pendidikan pada humanizing classrom menyebutkan bahwa individu belajar adanya dorongan untuk (1) menyadari diri sebagai suatu proses pertumbuhan yang sedang dan akan terus berubah (2) mencari konsep dan identitas diri , dan (3) memadukan kesadaran hati dan pikiran

Bertitik tolak dari tanggung jawabnya sebagai seorang yang telah bersertifikasi maka dengan demikian guru sangat perlu meningkatkan peranan dan kemampuan profesionalnya. Tanpa adanya kecakapan maksimal yang dimiliki oleh guru kiranya sulit bagi guru tersebut mengemban dan melaksanakan tanggung jawabnya dengan cara yang sebaik-baiknya. Peningkatan kemampuan itu meliputi kemampuan untuk melaksanakan tanggung jawab di dalam sekolah, dan kemampuan yang diperlukan untuk merealisasi tanggung jawabnya di luar sekolah, selanjutnya kemampuan-kemampuan itu harus dipupuk dalam diri pribadi guru.

Besarnya koefisien korelasi $(r)=0,6209$ peluang kesalahan $(p)=0,001$, dengan koefisien determinan $\left(\mathrm{r}^{2}\right)=0,3855$ merupakan sumbangan sertifikasi dan motivasi kerja terhadap minat guru bk mengikuti studi lanjut sebesar 38,55 \% adalah wujud relevansi dengan produk hukum tersebut di atas termasuk juga dalam pasal 29 diktum 4 dan 6 PP nomor 19 tahun 2005 tentang Standar Nasional Pendidikan.

Oemar Hamalik (2001:117) mengemukakan bahwa jabatan guru dikenal sebagai pekerjaan profesional, artinya jabatan ini memerlukan suatu keahlian khusus sebagaimana layaknya profesi lainnya. Pekerjaan ini tidak bisa dikerjakan oleh sembarang orang tanpa memiliki keahlian sebagai guru yang menguasai betul tentang seluk beluk pendidikan dan pengajaran serta ilmu-ilmu lainnya. Tambahan lagi bila dia telah mendapatkan pendidikan khusus untuk menjadi guru dan memiliki keahlian khusus dari pendidikan lanjut yang diperlukan untuk jenis pekerjaan ini maka sudah dapat dipastikan bahwa hasil usahanya akan lebih baik.

\section{Kesimpulan dan Saran}

Minat Guru Bimbingan Konseling untuk mengikuti pendidikan lanjut dipengaruhi oleh program sertifikasi, motivasi kerja, hal tersebut sebagai bentuk reformasi untuk meningkatkan kinerja serta komitmen terhadap pengembangan keprofesian berkelanjutan, dan secara bersama-sama dimensi program sertifikasi dan motivasi kerja tersebut berkontribusi 38,5\% terhadap minat guru. Dengan demikian, masih terdapat faktor lain 
yang lebih mendominasi dalam menjelaskan minat guru BK untuk mengikuti pendidikan lanjut.

Berdasarkan temuan penelitian ini, maka disarankan kepada lembaga penyelenggara pendidikan tinggi, sekolah, organisasi profesi perlu memiliki jalur formal dan informal yang mendorong terjadinya interaksi antara lembaga guna meningkatkan sosialisasi, serta kerja samanya.

\section{Daftar Pustaka}

Suharsimi Arikunto. 2002. Prosedur Penelitian. Jakarta : Rineka Cipta

Baharuddin. 2010. Teori Belajar dan Pembelajaran. Yogjakarta : Arr-Ruzz Media

Boyn, Tom. 2000. Comprehensive School Counseling. Idaho.Boise

2008. Buku 3 , Pedoman Penyusunan Portofolio, Dirjen Dikti, Departemen Pendidikan Nasional

Dahar, Ratna Wilis. 1988. Teori-teori Belajar. Jakarta : Dirjen Dikti LPTK

Depdiknas, 2008. Permendiknas Nomor 27 Tahun 2008, tentang :Standar Kualifikasi Akademik dan Kompetensi Konselor, Depdiknas

Sri Esti Wuryani Djiwandono. 2006. Psikologi Pendidikan. Jakarta : Gramedia Widiasarana Indonesia

Oemar Hamalik. 2004, Proses Belajar Mengajar, Jakarta : Bumi Aksara

Hergenhahn, Matthew H. Olson. 2008. Theories of Learning . St. Paul : Pearson Education Jawa Pos, 24 Agustus 2011

Andi Mappiere. 1983. Psikologi Orang Dewasa. Surabaya : Usaha Nasional

Mulyasa. 2005. Menjadi Kepala sekolah profesional, Bandung : Remaja Rosdakarya 2005. Peraturan Pemerintah RI Nomor 19 tahun 2005, tentang :Standar Nasional Pendidikan

2007. Peraturan Menteri Pendidikan Nasional Nomor 18 Tahun 2007, tentang Sertifikasi Bagi Guru Dalam Jabatan, Jakarta : Depdiknas

2008. Peraturan Pemerintah RI Nomor 74 tahun 2008, tentang : Guru

2009. Permenpan dan RB Nomor 16 tahun 2009, tentang : Jabatan Guru dan Angka Kreditnya 
Prayitno. 2008. Konseling Dasar-dasar Bimbingan. Jakarta :Rineka Cipta

Prayitno. 2008. Mengatasi Krisis Identitas Profesi Konselor. Padang

Sugiyono. 2010. Metode Penelitian Pendidikan. Bandung : Alfabeta

2011. Tujuan Sertifikasi Guru, lsmmper.blogspot.com

2003. Undang-undang RI Nomor 20 tahun 2003, tentang : Sistem Pendidikan Nasional

2005. Undang Nomor 14 Tahun 2005 tentang: Guru dan Dosen

Bimo Walgito. 2010. Bimbingan Konseling - Studi \& Karer. Yogjakarta : Andi

Zamroni. 2001. Pendidikan Untuk Demokrasi. Yogjakarta : Bigraf 